\title{
PERBANDINGAN KETERAMPILAN SOSIAL MELALUI MODEL PEMBELAJARAN KOOPERATIF TIPE CI DAN CLS
}

\author{
Rendika Vhalery ${ }^{1}$, Ani Interdiana Candra Sari ${ }^{2(*)}$, Ayi Ahmad Maulana Yusup ${ }^{3}$ \\ Universitas Indraprasta PGRI, Indonesia \\ rendikavhalery31@gmail.com ${ }^{1}$, incasani26@gmail.com², ayiahmad.my@gmail.com ${ }^{3}$
}

\begin{abstract}
Received: 02 September 2020 Tidak hanya kemampuan akademik yang menjadi faktor keberhasilan Revised: 08 September 2020 tujuan pembelajaran. Ada faktor lain yang dapat menjadi tolak ukur Accepted: 15 September 2020 keberhasilan yaitu keterampilan. Ada banyak jenis keterampilan yang perlu dikembangkan ketika proses pembelajaran berlangsung. Salah satunya adalah keterampilan sosial. Keterampilan sosial dapat dimanfaatkan didalam semua keadaan. Namun, tidak banyak dosen yang memperhatikan keterampilan sosial mahasiswa sehingga keterampilan sosial mereka menjadi tidak muncul ataupun berkembang. Kesalahan ini dapat diperbaiki melalui model pembelajaran kooperatif tipe CI dan CLS. Penelitian ini bertujuan untuk mengetahui pengaruh model pembelajaran kooperatif tipe CI terhadap keterampilan sosial mahasiswa, pengaruh model pembelajaran kooperatif tipe CLS terhadap keterampilan sosial mahasiswa, dan perbandingan keterampilan sosial melalui model pembelajaran kooperatif tipe CI dan CLS. Penelitian ini bersifat eksperimen dan komparatif. Populasi pada penelitian eksperimen ini adalah mahasiswa Universitas Indraprasta yang terdiri dari 2 kelas. Kelas pertama berjumlah 37 orang dan kelas kedua berjumlah 35 orang. Hasil menunjukkan bahwa ada pengaruh model pembelajaran kooperatif tipe CI terhadap keterampilan sosial mahasiswa, ada pengaruh model pembelajaran kooperatif tipe CLS terhadap keterampilan sosial mahasiswa, dan tidak ada perbandingan keterampilan sosial melalui model pembelajaran kooperatif tipe CI dan CLS.
\end{abstract}

Keywords: CI; CLS; Keterampilan Sosial; Pembelajaran Kooperatif

(*) Corresponding Author: $\quad$ Sari, incasani26@gmail.com, 081282417766

How to Cite: Vhalery, R., Sari, A. I. C., \& Yusup, A. A. M. (2020). Perbandingan Keterampilan Sosial Melalui Model Pembelajaran Kooperatif Tipe CI Dan CLS. Research and Development Journal of Education, 1(1), 60-71.

\section{INTRODUCTION}

Pendidikan tidak hanya berperan dalam mengembangkan kemampuan akademik melainkan kemampuan lainnya seperti keterampilan sosial (Kurniati, 2011). Keterampilan sosial adalah kemampuan berkomunikasi, bekerjasama, berbagi, berpartisipasi, dan beradaptasi (Perdani, 2014). Keterampilan sosial tidak hanya bersifat verbal seperti berbicara, bisa juga bersifat non verbal seperti menggunakan gerak badan (Siska, 2011). Keterampilan sosial berfungsi sebagai sarana untuk memperoleh hubungan yang baik pada saat berinteraksi dengan orang lain. Pentingnya keterampilan sosial bagi mahasiswa sangat diperlukan untuk diterapkan dalam proses pembelajaran (Bali, 2017). Mahasiswa yang memiliki keterampilan sosial tinggi mempunyai potensi untuk melakukan interaksi atau komunikasi secara mudah, berkomunikasi aktif untuk membicarakan berbagai hal bersama teman atau dengan dosen di kampus (Dewanti et al., 2016). Sedangkan mahasiswa yang memiliki keterampilan sosial rendah biasanya terkucilkan, tidak pandai atau jarang berkomunikasi dengan dosen atau teman, tidak 
konsentrasi belajar, kurang bersosialisasi, tidak ingin terlibat organisasi atau sejenisnya, dan slow respon (Bakhtiar, 2015).

Untuk mengetahui apakah mahasiswa Universitas Indraprasta (Unindra) memiliki keterampilan sosial yang tinggi atau rendah. Peneliti melakukan studi awal dengan cara membagikan kuesioner untuk mengetahui tingkat keterampilan sosial mereka. Hasil studi awal menunjukkan bahwa 68,2\% mahasiswa memiliki keterampilan sosial yang rendah. Sedangkan 31,8\% mahasiswa memiliki keterampilan sosial yang tinggi. Rendahnya keterampilan ini dipengaruhi oleh berbagai macam faktor seperti teman, kelompok, lingkungan, dan latar belakang individu. Untuk meningkatkan keterampilan sosial, dosen perlu memilih dan menggunakan strategi pembelajaran yang tepat agar tujuan yang diharapkan dapat tercapai dengan optimal (Suherman, 2016). Model pembelajaran kooperatif dapat menumbuhkan atau meningkatkan keterampilan sosial mahasiswa (Indrastoeti \& Mahfud, 2015). Ada banyak tipe model pembelajaran kooperatif (Vhalery, 2019a, 2019b), diantaranya complex instruction dan cooperative learning sctructures.

Model pembelajaran kooperatif tipe CI (complex instruction) merupakan model pembelajaran yang mempunyai prinsip dan praktik untuk melakukan kerja kelompok secara kolaboratif untuk mempromosikan kesetaraan dan ketelitian (Oslund, 2016). Fokus utama Model pembelajaran kooperatif tipe CI adalah membangun kepercayaan pada semua kemampuan yang dimiliki mahasiswa, mereka dikumpulkan dalam kelompokkelompok kooperatif dengan komposisi yang beragam seperti kemampuan, etnik, maupun bahasa (Purmintasari \& Lestari, 2016). Model pembelajaran kooperatif tipe CI tidak hanya menjadikan mahasiswa sebagai pendengar, tapi ikut serta secara aktif dalam penemuan dan pengembangan pengetahuannya (Nursafitri et al., 2020).

Penelitian penggunaan model pembelajaran kooperatif tipe CI (complex instruction) sudah banyak diteliti oleh peneliti. Namun, tidak banyak peneliti yang menggunakan model pembelajaran kooperatif tipe CI (complex instruction) untuk meninjau sisi keterampilan sosial mahasiswa. Oleh karena itu peneliti ingin menggunakan model pembelajaran kooperatif tipe CI (complex instruction) untuk meneliti keterampilan sosial mahasiswa. Selain itu, peneliti juga akan membandingkan keterampilan sosial mahasiswa melalui model ini dan model pembelajaran kooperatif tipe lainnya.

Model pembelajaran kooperatif tipe lainnya adalah CLS (cooperative learning structures). cooperative learning sctructures merupakan model pembelajaran yang terstruktur pada saat pelaksanaannya. Untuk menggunakan model pembelajaran kooperatif tipe CLS, instruktur perlu merencanakan dengan hati-hati setiap kegiatan kelas, karena perencanaan ini akan memberikan banyak manfaat pada pemahaman mahasiswa yang lebih dalam tentang materi pelajaran dan apresiasi proses pembelajaran (Jr. \& Millis, 1994).Model pembelajaran kooperatif ini dapat menumbuhkan mahasiswa menjadi aktif, kreatif, dan kritis (Nurokhman, 2014). Sesuai dengan fungsi utamanya yaitu mengajar, mempertanyakan, dan mengkritik (Jr. \& Millis, 1994). Disisi lain, pendidik berpartisipasi untuk membina untuk membangun kepercayaan diri mereka, mendorong mereka untuk sering berinteraksi dan memberikan umpan balik yang tidak menghakimi (Wineburg, 1995). Model ini juga mampu meningkatkan kemampuan berpikir, meningkatkan kesadaran, pemecahan masalah (Cline, 2007).

Penelitian penggunaan model pembelajaran kooperatif tipe CLS (cooperative learning structures) juga sudah banyak diteliti oleh peneliti. Namun, tidak banyak peneliti yang menggunakan model pembelajaran kooperatif tipe CLS (cooperative learning structures) untuk meninjau keterampilan sosial mahasiswa. Oleh karena itu peneliti ingin menggunakan model pembelajaran kooperatif tipe CLS (cooperative learning structures)untuk meneliti keterampilan sosial mahasiswa. Selain itu, peneliti juga akan membandingkan keterampilan sosial mahasiswa melalui model ini dengan model pembelajaran kooperatif tipe CI (complex instruction). 
Tujuan dari penelitian ini yaitu untuk mengetahui ada atau tidak ada pengaruh model pembelajaran kooperatif tipe CI terhadap keterampilan sosial mahasiswa, untuk mengetahui ada atau tidak ada pengaruh model pembelajaran kooperatif tipe CLS terhadap keterampilan sosial mahasiswa, ada atau tidak ada perbandingan keterampilan sosial melalui model pembelajaran kooperatif tipe CI dan CLS

\section{LITERATURE REVIEW}

\section{CI (Complex Instruction)}

Menurut Cohen et al. (1999) model pembelajaran kooperatif tipe complex instruction (CI) adalah pendekatan instruksional yang memungkinkan mahasiswa mampu menjawab pertanyaan-pertanyaan dari dosen dengan baik. Disisi lain, Nurhikmah et al. (2017) mendefinisikan pembelajaran kooperatif tipe complex instruction sebagai model pembelajaran kooperatif yang menekankan pentingnya penerapan proyek yang berorientasi pada penemuan. Sedangkan Nursafitri et al. (2020) mengungkapkan bahwa model pembelajaran kooperatif tipe CI merupakan model pembelajaran yang memiliki struktur yang mempertimbangkan berbagai kecerdasan majemuk, sehingga semua mahasiswa terlibat dalam pembelajaran dan menyumbangkan gagasannya karena setiap mahasiswa pada umumnya memilki jenis kecerdasan yang berbeda. Dari beberapa pendapat tersebut dapat disimpulkan bahwa model pembelajaran kooperatif tipe complex instruction merupakan model pembelajaran yang yang disesuaikan dengan kemampuan atau kecerdasan mahasiswa agar mampu memahami, meningkatkan, mengembangkan, serta mencari solusi atas permasalahan yang disediakan oleh dosen.

Samosir \& Silitonga (2014) menjelaskan secara singkat sintaks penerapan model pembelajaran kooperatif tipe CI. Pertama, dosen menyiapkan sejumlah materi pembelajaran dan membentuk kelompok yang terdiri dari 4 orang. Kedua, dosen menyiapkan sejumlah kartu peran dan menjelaskan tugas masing-masing peran (fasilitator, kapten tim, pencatat, dan manajer sumber daya) kemudian mahasiswa mengambil secara acak kartu peran. Ketiga, dosen memulai presentasi singkat sebagai pemandu awal dan membagikan bahan ajar yang telah disiapkan kepada masingmasing kelompok. Keempat, mahasiswa memulai diskusi kelompok sesuai perannya dan mencoba menyelesaikan masalah yang ada, kemudian mempresentasikan hasil yang dilakukan oleh kapten tim. Kelima, setelah semua kelompok melakukan presentasi dan masih ada waktu, setiap kelompok mengambil bahan ajar yang lain dan bertukar peran. Keenam, refleksi dengan arahan dosen. Ketujuh, asesmen individual terkait bahan ajar.

Ada beberapa unsur pada model pembelajaran kooperatif tipe CI yaitu norma, aturan, berbagi tugas sesuai kemampuan individu, dan status (Hackett, 2019). Model pembelajaran kooperatif tipe CI memiliki beberapa kelebihan, yaitu setiap anggota kelompok mampu mempertanggungjawabkan materi pembelajaran secara individu maupun berkelompok, menimbulkan rasa nyaman dalam mengerjakan tugas yang telah diberikan, dan juga dapat meningkatkan rasa solidaritas dalam kelompok (Agusprianti et al., 2018). Selain itu, ada beberapa kelemahan pada model pembelajaran. Pertama, seringkali dosen kesulitan untuk membuat kelompok yang terdiri dari beragam kemampuan yang dimiliki mahasiswa karena mahasiswa harus diberi peran sesuai dengan kemampuan yang mereka miliki. Kedua, terkadang dalam pembagian kelompok, masih ada mahasiswa yang masih tidak nyaman dalam 
kelompoknya sehingga terjadi kegaduhan dalam pembagian kelompok yang mengakibatkan akan menganggu kelas yang berdekatan (Sustianah, 2014).

\section{CLS (Cooperative Learning Sctructures)}

Dyson \& Grineski (2001) menyatakan bahwa cooperative learning sctructures merupakan pembelajaran kooperatif untuk kegiatan yang melampaui permainan kooperatif sederhana, mereka perlu memahami dan menuangkan ke dalam struktur pembelajaran kooperatif yang praktis. struktur ini adalah metode yang mengatur mahasiswa untuk berinteraksi selama proses pembelajaran berlangsung. Pada hakikatnya, cooperative learning structure merupakan proses pembelajaran dimana semua mahasiswa memiliki kesempatan yang sama untuk aktif dalam mengemukakan pendapat, mendapatkan kesempatan yang sama untuk memberikan kontribusi, serta mendengarkan pendapat dan pemikiran anggota yang lain (Purwaningsih, 2018).

Ada beberapa langkah untuk menerapkan model pembelajaran kooperatif tipe CLS yaitu orientasi (orientation), pemunculan gagasan (elicitation of ideas), penyusunan ulang gagasan, perubahan dan perluasan (restructuring, modification and extension), aplikasi (application) (Purwaningsih, 2018). Lebih lanjut, Rukmana (2017) menjelaskan langkah penerapan model pembelajaran kooperatif tipe CLS yaitu pembentukan kelompok yang terdiri dari dua orang (berpasangan) atau lebih, salah satunya bertindak sebagai tutor dan yang lain menjadi tutee. Tutor mengajukan pertanyaan yang harus dijawab oleh tutee, apabila jawaban tutee benar, ia memperoleh poin atau skor yang telah ditetapkan, lalu berganti peran setelah waktu yang telah ditetapkan.

Manfaat dari penggunaan model pembelajaran kooperatif tipe CLS yaitu membantu mahasiswa mengembangkan keterampilan mahasiswa dengan cara menekankan keterampilan metakognitif, mahasiswa terlibat aktif, meningkatkan keterampilan belajar, mereka lebih bertanggung jawab untuk memahami materi, mengembangkan keterampilan berlajar, bertanya, dan mengevaluasi, saling ketergantungan positif dan akuntabilitas individu, serta merangsang beberapa hasil kognitif dan afektif mahasiswa (Jr. \& Millis, 1994).

\section{Keterampilan Sosial}

Keterampilan sosial merupakan salah satu aspek perkembangan individu yang sangat penting dalam menentukan keberhasilan mereka untuk memulai dan memiliki hubungan sosial, Selain itu kemampuan individu dalam kerjasama juga penting untuk suatu kegiatan atau pergaulan berkelompok (Isbayani et al., 2015). Menurut Agustriana (2018) keterampilan sosial adalah pengetahuan tentang interaksi sosial (perilaku manusia dan proses antarpribadi, kemampuan memahami perasaan, sikap, motivasi, kemampuan untuk berkomunikasi dengan jelas dan efektif, serta kemampuan membangun hubungan yang efektif dan kooperatif). Sedangkan Izzati (2014) mendefinisikan keterampilan sosial sebagai kemampuan yang dimiliki mahasiswa untuk menempatkan diri dan mengambil peran yang sesuai di lingkungannya. Berdasarkan pendapat para ahli disimpulkan bahwa keterampilan sosial merupakan salah satu kemampuan berdasarkan pengetahuan untuk menempatkan diri dan mengambil peran melalui interaksi sosial di lingkungan sekitar.

Keterampilan sosial yang perlu dimiliki yaitu living and working together, taking turns, respecting the rights of others, being socially sensitive, learning selfcontrol, learning self-direction, sharing ideas, and social experience with others (Agustriana, 2013). Keterampilan ini didapat apabila individu telah memiliki unsur penunjang keterampilan sosial. Maryani \& Syamsudin (2009) mengungkapkan 
beberapa unsur pada keterampilan sosial yaitu kepercayaan (perasaan saling percaya yang memungkinkan untuk saling Bersatu), relasi mutual (kecenderungan saling tukar kebaikan antar individu dalam suatu kelompok atau antar kelompok itu sendiri), norma sosial (sekumpulan aturan yang diharapkan, dipatuhi, dan diikuti oleh kelompok, nilai sosial (sesuatu yang dianggap penting), sikap proaktif (sikap yang ditampilkan oleh individu anggota kelompok untuk selalu terlibat dengan ide-ide baru pemecahan masalah dalam partisipasi sosial mereka).

Perdani (2013) menyebutkan ciri-ciri keterampilan sosial. Pertama, perilaku interpersonal yang merupakan perilaku untuk melakukan interaksi sosial atau keterampilan menjalin persahabatan (contohnya: memperkenalkan diri, menawarkan bantuan dan memberikan atau menerima pujian). Kedua, perilaku yang berhubungan dengan diri sendiri (contohnya: menghadapi stres, memahami perasaan orang lain, mengontrol emosi) yang dapat membaca situasi atau dapat memperkirakan dampak dari pengambilan keputusan. Ketiga, perilaku yang berhubungan dengan kesuksesan akademis seperti motivsi yang mendukung prestasi belajar (contohnya: mendengarkan penjelasan dosen, mengerjakan tugas, menuruti permintaan dosen). Kelima, keterampilan komunikasi untuk menjalin hubungan sosial yang baik (contohnya: menjadi pendengar yang responsif, mempertahankan perhatian dalam pembicaraan dan memberikan umpan balik terhadap kawan bicara). Indikator keterampilan sosial yaitu keterampilan berkomunikasi, keterampilan menulis, keterampilan bekerjasama, dan keterampilan mengendalikan konflik atau empati (Wardani, 2019).

\section{METHODS}

Penelitian ini adalah penelitian eksperimen dan komparatif. Penelitian eksperimen ini menggunakan Completely Randomized Design yanga artinya penelitian eksperimen ini tidak menggunakan kelas kontrol. Hal ini dikarenakan peneliti menggunakan 2 model pembelajaran kooperatif tipe CI (complex instruction) dan CLS (cooperative learning sctructures) yang akan di eksperimen kan. Penelitian komparatif untuk membandingkan kedua model pembelajaran tersebut. Populasi pada penelitian eksperimen ini adalah mahasiswa Universitas Indraprasta yang terdiri dari 2 kelas. Kelas pertama berjumlah 37 orang dan kelas kedua berjumlah 35 orang. Teknik pengumpulan data pada penelitian ini adalah kuesioner yang digunakan untuk mendapatkan hasil aktivitas belajar dan dokumentasi untuk mendapatkan hasil secara langsung (nilai uts dan uas).

Tahap pelaksanaan pada penelitian eksperimen ini dibagi menjadi 3 bagian yaitu pelaksanaan awal, pelaksanaan inti, dan pelaksanaan akhir. Pada tahap pelaksanaan awal, peneliti membagikan kuesioner kepada mahasiswa untuk mengetahui keterampilan sosial mahasiswa sebelum penggunaan model pembelajaran kooperatif tipe CI dan CLS. Pada tahap pelaksanaan inti, peneliti menentukan model pembelajaran kooperatif tipe CI dan CLS pada dua kelas eksperimen. Kelas Eksperimen 1 menggunakan model pembelajaran kooperatif tipe CI dan kelas eksperimen 2 menggunakan model pembelajaran kooperatif tipe CLS. Pelaksanaan model ini dilakukan beberapa kali pada saat pertemuan tatap muka. Pada tahap pelaksanaan akhir, peneliti membagikan kuesioner lagi kepada mahasiswa untuk mengetahui keterampilan sosial setelah penggunaan model pembelajaran kooperatif tipe CI dan CLS. Setelah itu, data di analisis dan disimpulkan dengan menggunakan rumus statistik deskriptif dan lainnya. 


\section{RESULTS \& DISCUSSION}

\section{Result}

Data penelitian yang telah didapatkan diolah untuk mengetahui kesimpulan dari penelitian. Pengolahan data diawali dengan mendeskripsikan data penelitian. Hasil penelitian uji deskriptif dapat dilihat pada tabel berikut.

Tabel 1.

Hasil Uji Deskriptif

\begin{tabular}{lc|c|c|c|c}
\hline & N & Minimum & Maximum & Mean & Std. Deviation \\
\hline Pre Eksperimen CI & 37 & 60 & 80 & 67,62 & 7,061 \\
\hline Post Eksperimen CI & 37 & 60 & 90 & 74,19 & 9,294 \\
\hline Pre Eksperimen CLS & 35 & 60 & 85 & 67,14 & 7,076 \\
\hline Post Eksperimen CLS & 35 & 60 & 90 & 72,86 & 6,454 \\
\hline Valid N (listwise) & 35 & & & & \\
\hline
\end{tabular}

Sumber : Hasil Output SPSS versi 24.0

Dari tabel 1 diketahui jumlah sampel pada kelas eksperimen sebanyak 37 orang di eksperimen 1 dan sebanyak 35 orang di kelas eksperimen 2. Nilai minimum untuk pre dan post eksperimen CI dan CLS sebesar 60. Nilai maximum pre eksperimen CI dan CLS sebesar 80 dan 85, nilai maximum post eksperimen CI dan CLS sebesar 90. Nilai mean pre eksperimen CI sebesar 67,62 dan CLS sebesar 67,14, nilai mean post eksperimen CI sebesar 74,19 dan CLS sebesar 72,86. Nilai standar deviasi pre eksperimen CI sebesar 7,061 dan CLS sebesar 7,076, nilai standar deviasi post eksperimen CI sebesar 9,294 dan CLS sebesar 6,454.

Pengujian berikutnya adalah uji normalitas data untuk mengetahui apakah data penelitian bersifat normal atau tidak normal. Uji normalitas data pada penelitian eksperimen ini menggunakan uji Kolmogorov-Smirnov dan uji Shapiro-Wilk. Pengambilan keputusan berdasarkan 2 keadaan, apabila nilai sig. $>0.050$ maka data bersifat normal dan apabila nilai sig. $<0.050$ maka data tidak bersifat normal. Hasil uji Kolmogorov-Smirnov dan uji Shapiro-Wilk dapat dilihat pada tabel berikut ini.

Tabel 2.

Hasil Uji Normalitas

\begin{tabular}{llcccccc}
\hline \multirow{2}{*}{ Kelas } & \multicolumn{2}{c}{ Kolmogorov-Smirnov } & \multicolumn{3}{c}{ Shapiro-Wilk } \\
& Statistic & df & Sig. & Statistic & df & Sig. \\
\hline Model & Pre Eksperimen CI &, 265 & 37 &, 000 &, 831 & 37 &, 000 \\
& Post Eksperimen CI &, 099 & 37 &, 200 &, 945 & 37 &, 068 \\
& Pre Eksperimen CLS &, 215 & 35 &, 000 &, 858 & 35 &, 000 \\
& Post Eksperimen CLS &, 113 & 35 &, 200 &, 974 & 35 &, 561 \\
\hline
\end{tabular}

Sumber : Hasil Output SPSS versi 24.0

Tabel 2 menunjukkan hasil uji Kolmogorov-Smirnov dan uji Shapiro-Wilk untuk pre eksperimen model complex instruction tidak bersifat normal, sedangkan hasil uji Kolmogorov-Smirnov dan uji Shapiro-Wilk untuk post eksperimen model complex instruction bersifat normal. Selain itu, hasil uji Kolmogorov-Smirnov dan uji ShapiroWilk untuk pre eksperimen model cooperative learning structure juga tidak bersifat normal, dan hasil uji Kolmogorov-Smirnov dan uji Shapiro-Wilk untuk post eksperimen model cooperative learning structure bersifat normal. Secara keseluruhan dapat disimpulkan bahwa data tidak bersifat normal. Karena data tidak bersifat normal maka pengujian selanjutnya menggunakan uji statistik non parametrik. 
Uji statistik non parametrik yang digunakan apabila data tidak bersifat normal yaitu uji wilcoxon. Adapun ketentuan pengambilan keputusan pada uji wilcoxon yaitu jika nilai asymp. sig. < 0.050 maka ada pengaruh model pembelajaran kooperatif tipe CI atau CLS pada keterampilan sosial mahasiswa dan jika nilai asymp. sig. $>0.050$ maka tidak ada pengaruh model pembelajaran kooperatif tipe CI atau CLS pada keterampilan sosial mahasiswa. Hasil uji wilcoxon dapat dilihat pada tabel berikut ini.

Tabel 3.

Hasil Uji Wilcoxon

\begin{tabular}{lcc}
\hline & $\begin{array}{l}\text { Post Eksperimen CI - Post Eksperimen CLS - } \\
\text { Pre Eksperimen CI }\end{array}$ & \begin{tabular}{c} 
Pre Eksperimen CLS \\
\hline$Z$
\end{tabular} \\
\hline Asymp. Sig. (2-tailed) & $-4,270$ & $-3,705$ \\
\hline
\end{tabular}

Sumber : Hasil Output SPSS versi 24.0

Hasil uji wilcoxon pada tabel 3 untuk nilai pre dan post model pembelajaran kooperatif tipe CI menunjukkan nilai asymp. sig. sebesar $0.000<0,050$ yang artinya, model pembelajaran kooperatif tipe CI berpengaruh terhadap keterampilan sosial mahasiswa. Nilai pre dan post model pembelajaran kooperatif tipe CLS juga menunjukkan nilai asymp. sig. sebesar $0.000<0,050$ yang artinya, model pembelajaran kooperatif tipe CLS juga berpengaruh terhadap keterampilan sosial mahasiswa.

Pengujian selanjutnya dilakukan untuk mengetahui apakah ada perbandingan penggunaan model pembelajaran kooperatif tipe CI dengan CLS terhadap keterampilan sosial mahasiswa. Statistik non parametrik yang digunakan yaitu uji Mann-Whitney. Pengambilan keputusan pada uji mann-whitney jika nilai Asymp. Sig. $>0.050$ maka tidak ada perbedaan penggunaan model pembelajaran kooperatif tipe CI dan CLS terhadap keterampilan sosial mahasiswa, dan jika nilai Asymp. Sig. $<0.050$ maka ada perbedaan penggunaan model pembelajaran kooperatif tipe CI dan CLS terhadap keterampilan sosial mahasiswa. Hasil uji Mann-Whitney dapat dilihat pada tabel berikut ini.

Tabel 4.

Hasil Pengujian Mann-Whitney Test Statistics

\begin{tabular}{lc}
\hline Mann-Whitney U & 579,500 \\
\hline Wilcoxon W & 1209,500 \\
\hline$Z$ &, 770 \\
\hline Asymp. Sig. (2-tailed) &, 441 \\
\hline Sumber : Hasil Output SPSS versi 24.0
\end{tabular}

Hasil uji mann-whitney pada tabel 4 menunjukkan bahwa nilai asymp. sig. Sebesar 0.469 yang lebih besar dari 0.050 yang artinya tidak ada perbandingan keterampilan sosial melalui model pembelajaran kooperatif tipe CI dan CLS.

\section{Discussion}

1. Model pembelajaran kooperatif tipe CI pada keterampilan sosial mahasiswa

Hasil uji statistik non-parametrik menunjukkan bahwa model pembelajaran kooperatif tipe CI berpengaruh terhadap keterampilan sosial mahasiswa. Sebagai pembelajaran kooperatif, model ini sesuai dan menjanjikan untuk ruang kelas yang heterogen secara akademis dan bahasa (Cohen et al., 1999). Lebih lanjut, Samosir 
\& Silitonga (2014) menjelaskan bahwa kelas yang diajar dengan model pembelajaran kooperatif tipe complex instruction akan mendorong mahasiswa untuk aktif dalam memecahkan kesulitan dari konsep-konsep pelajaran, dan mereka mempunyai kesempatan untuk menggunakan daya kreatifitasnya. Model pembelajaran kooperatif tipe complex instruction memiliki misi untuk memberikan kepedulian dalam menggali potensi yang dimiliki mahasiswa, bahkan memberikan keyakinan bahwa setiap mahasiswa memiliki keunggulan sehingga dapat membantu keberhasilan kelompok (Nurhikmah et al., 2017).

Dilihat dari sisi pelaksanaan eksperimen model pembelajaran kooperatif tipe CI. Nilai pre eksperimen terendah adalah 60 dan nilai tertinggi adalah 80 dengan nilai rata-rata sebesar 67,62. Nilai post eksperimen terendah adalah 60 dan nilai tertinggi adalah 90 dengan nilai rata-rata sebesar 74,19 . Perbandingan rata-rata secara keseluruhan antara pre dan post hanya meningkat sebesar 6,57. Perbedaan ini dapat dilihat pada gambar berikut ini.

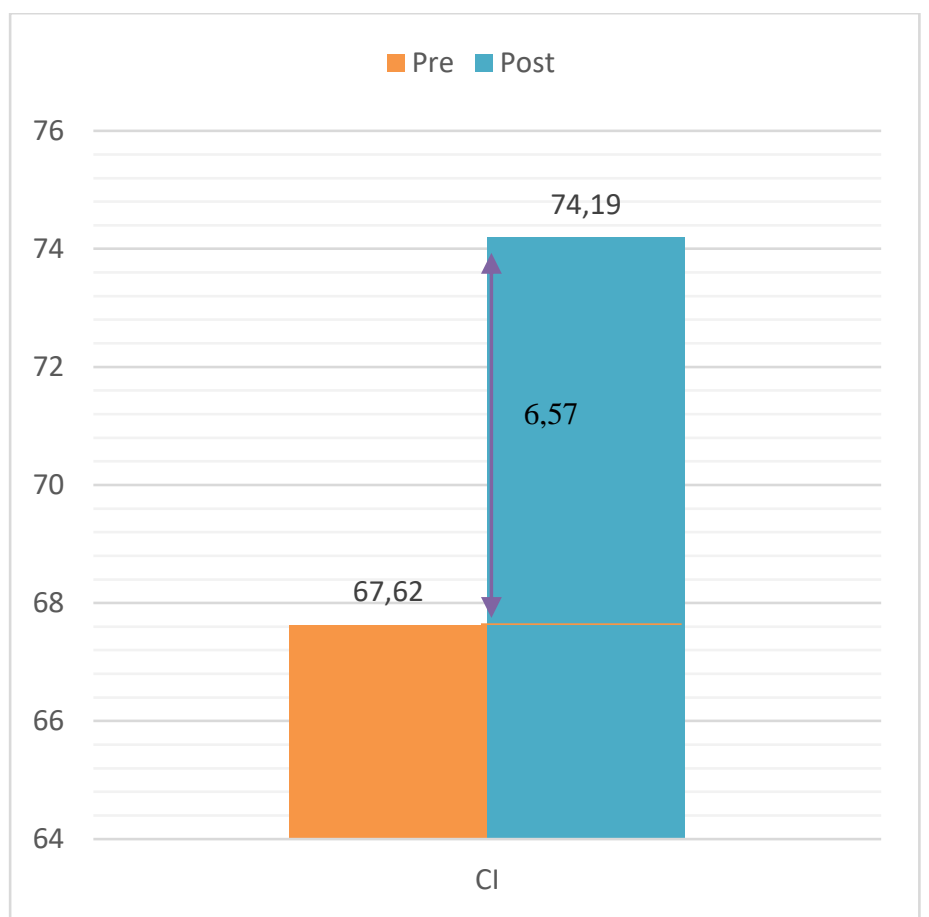

Sumber : Hasil Output SPSS versi 24.0

Gambar 1.

Nilai Pre dan Post Model Pembelajaran Kooperatif Tipe CI

2. Model pembelajaran kooperatif tipe CLS pada keterampilan sosial mahasiswa

Hasil uji statistik non-parametrik menunjukkan bahwa model pembelajaran kooperatif tipe CLS berpengaruh terhadap keterampilan sosial mahasiswa. Dalam pembelajaran cooperative learning structure, mahasiswa tidak hanya menerima apa yang disampaikan oleh dosen, tetapi turut berpartisipasi aktif dalam proses pembelajaran yaitu bagaimana cara menggali ide terhadap materi untuk disampaikan kepada teman- temannya (Purwaningsih, 2018). Hal ini menunjukkan bahwa model pembelajaran kooperatif tipe CLS mengutamakan kerja sama (sosial) yang mengacu pada keterampilan sosial sehingga memberikan dampak secara langsung. Tidak hanya itu, model ini berpengaruh juga dikarenakan pelaksanaannya mengacu kepada jiwa sosial mahasiswa. 
Dilihat dari sisi pelaksanaan eksperimen model pembelajaran kooperatif tipe CLS. Nilai pre eksperimen terendah adalah 60 dan nilai tertinggi adalah 85 dengan nilai rata-rata sebesar 67,14 . Nilai post eksperimen terendah adalah 60 dan nilai tertinggi adalah 90 dengan nilai rata-rata sebesar 72,86 . Perbandingan rata-rata secara keseluruhan antara pre dan post hanya meningkat sebesar 5,71. Perbedaan ini dapat dilihat pada gambar berikut ini.

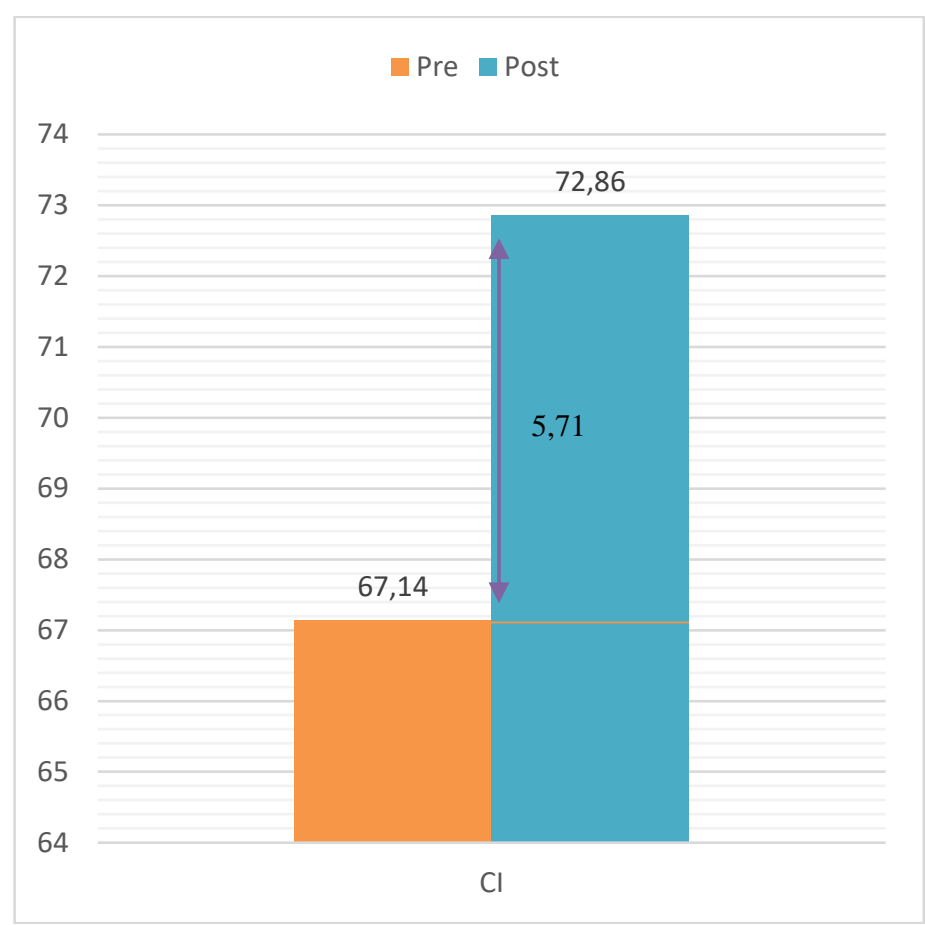

Sumber : Hasil Output SPSS versi 24.0

Gambar 2.

Nilai Pre dan Post Model Pembelajaran Kooperatif Tipe CLS

3. Perbandingan keterampilan sosial melalui model pembelajaran kooperatif tipe CI dan cls

Hasil uji statistik non-parametrik menunjukkan bahwa tidak ada perbandingan keterampilan sosial mahasiswa melalui model pembelajaran kooperatif tipe CI dan CLS. Tidak adanya perbedaan pada keterampilan sosial melalui model pembelajaran kooperatif tipe CI dan CLS dikarenakan kedua model ini sama-sama berorientasi pada sosial. Maksudnya, mulai dari penerapan model sudah merujuk pada kebersamaan (sosial) seperti pembentukan kelompok. Lalu berkomunikasi sesama anggota, bertukar pikiran atau pendapat, sedikit pro dan kontra terhadap suatu argument yang menunjukkan adanya keterampilan sosial. Tidak hanya itu, tidak adanya perbedaan pada keterampilan sosial menunjukkan bahwa model pembelajaran kooperatif tipe CI dan / atau CLS mampu memberikan kontribusi yang sama terhadap keterampilan sosial mahasiswa.

Perbandingan pada saat pelaksanaan eksperimen model pembelajaran kooperatif tipe CI dan CLS. Nilai pre eksperimen terendah untuk model pembelajaran kooperatif tipe CI dan CLS adalah 60 dan nilai tertinggi model pembelajaran kooperatif tipe CI sebesar 80 dan CLS sebesar 85, dengan nilai ratarata sebesar 67,62 dan 67,14. Perbandingan nilai pre antara model pembelajaran kooperatif tipe CI dan CLS adalah 0,48, yang didominasi oleh model pembelajaran kooperatif tipe CI. Nilai post eksperimen model pembelajaran kooperatif tipe CI 
dan CLS adalah 60, sedangkan nilai tertinggi model pembelajaran kooperatif tipe CI dan CLS adalah 90, dengan nilai rata-rata sebesar 74,19 dan 72,86. Perbandingan nilai post antara model pembelajaran kooperatif tipe CI dan CLS adalah 1,33, yang didominasi oleh model pembelajaran kooperatif tipe CI. Perbedaan ini dapat dilihat pada gambar berikut ini.

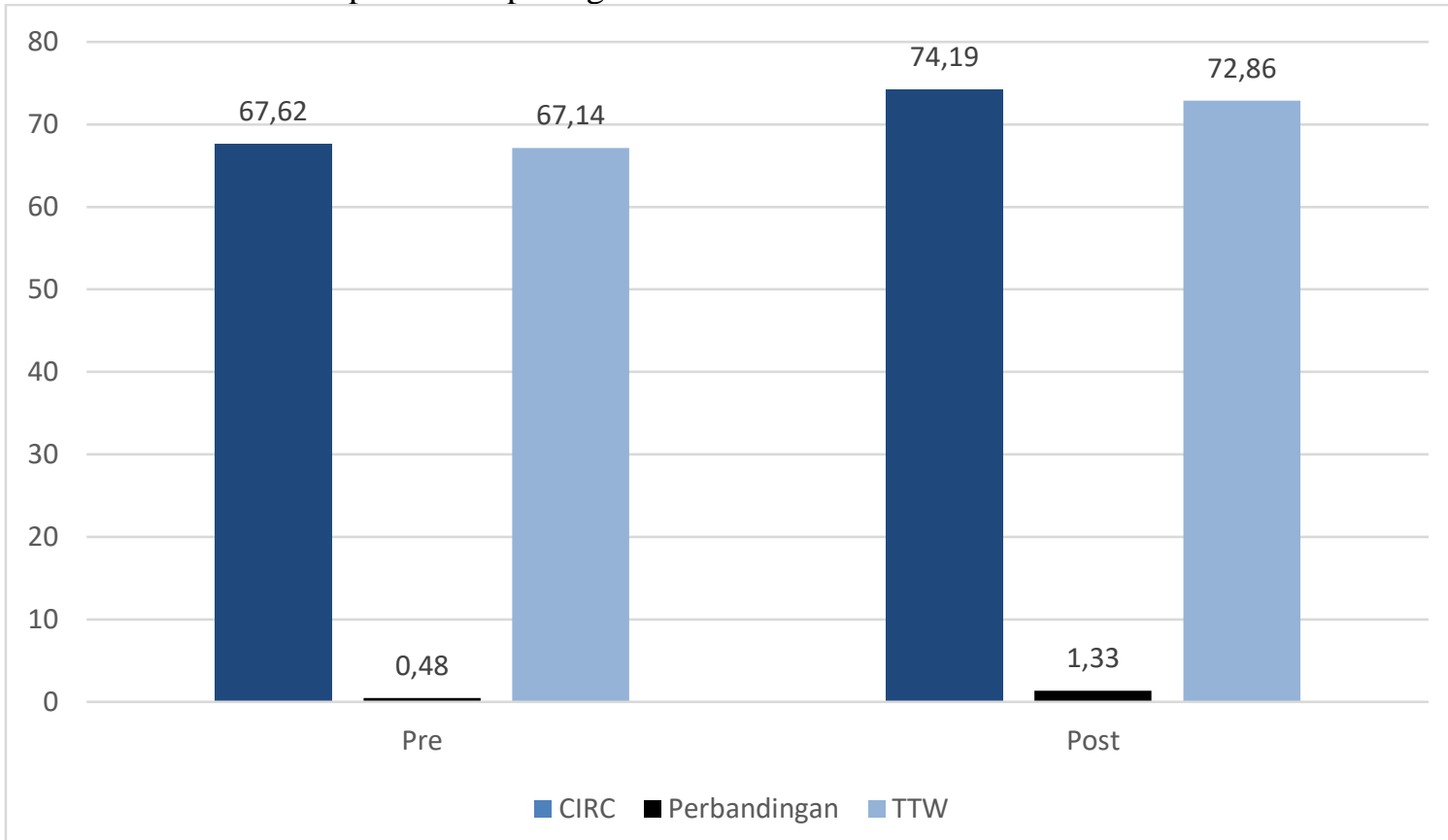

Sumber : Hasil Output SPSS versi 24.0

Gambar 3.

Perbandingan Model Kooperatif Tipe CI dan CLS pada Keterampilan Sosial

\section{CONCLUSION}

Berdasarkan hasil dan pembahasan yang telah disampaikan maka dapat disimpulkan sebagai berikut.

1. Ada pengaruh model pembelajaran kooperatif tipe CI terhadap keterampilan sosial mahasiswa.

2. Ada pengaruh model pembelajaran kooperatif tipe CLS terhadap keterampilan sosial mahasiswa.

3. Tidak ada perbedaan keterampilan sosial melalui model pembelajaran kooperatif tipe CI dan CLS.

Ada beberapa saran yang dapat diberikan pada saat pelaksanaan model pembelajaran kooperatif tipe CI dan CLS yaitu perhatikan materi ajar yang akan disampaikan (karena tidak semua materi ajar bisa diterapkan dengan model pembelajaran ini), pembentukan kelompok (perbedaan kapasitas akademik yang dimiliki mahasiswa, terkadang diabaikan oleh guru/dosen), dan kesimpulan dari diskusi atau pembelajaran (pada saat penutupan, kebanyakan guru/dosen mengabaikan untuk meluruskan kembali hasil persentasi dari mahasiswa, bahkan tidak memberikan penguatan dari hasil pembelajaran yang dilaksanakan). Dan untuk penelitian dimasa mendatang, gunakan variabel selain keterampilan sosial pada saat membandingkan kedua model 


\section{REFERENCES}

Agusprianti, Rais, M., \& Mustarin, A. (2018). Aplication Ofcooperative Learning Type Complex Instruction (CI) To Improve Learning Outcomes In Vegetables Agribusiness Class XI Atph Vocational High School Number 4 Luwu. Jurnal Pendidikan Teknologi Pertanian, 4.

Agustriana, N. (2013). Pengaruh Metode Edutainment Dan Konsep Diri Terhadap Keterampilan Sosial Anak. Jurnal Pendidikan Usia Dini, 7(2).

Agustriana, N. (2018). Pengaruh Metode Edutainment Dan Identitas Diri Terhadap Keterampilan Sosial Anak. Al Fitrah: Journal Of Early Childhood Islamic Education, 2(1).

Bakhtiar, M. I. (2015). Pengembangan Video Ice Breaking Sebagai Media Bimbingan Konseling Dalam Meningkatkan Keterampilan Sosial. Jurnal Psikologi Pendidikan Dan Konseling, 1(2), 150.

Bali, M. M. E. I. (2017). Model Interaksi Sosial dalam Mengelaborasi Keterampilan Sosial. Jurnal Pedagogik, 4(2), 211-227.

Cline, L. M. (2007). Impacts of Kagan Cooperative Learning Structures on FifthGraders' Mathematical Achievement.

Cohen, E. G., Lotan, R. A., Scarloss, B. A., \& Arellano, A. R. (1999). Complex instruction: Equity in cooperative learning classrooms. Theory into Practice, 38(2), $80-86$.

Dewanti, T. C., Widada, \& Triyono. (2016). Hubungan Antara Keterampilan Sosial Dan Penggunaan Gadget Smartphone Terhadap Prestasi Belajar Siswa Sma Negeri 9 Malang. Jurnal Kajian Bimbingan Dan Konseling, 1(3), 126-131. https://doi.org/10.17977/um001v1i32016p126

Dyson, B., \& Grineski, S. (2001). Using Cooperative Learning Structures in Physical Education. Journal of Physical Education, Recreation \& Dance, 72(2), 28-31.

Hackett, M. (2019). The Role of Complex Instruction in the Pursuit of Learning Goals : It 's A Marathon, Not a Sprint.

Indrastoeti, J., \& Mahfud, H. (2015). Pembelajaran Kooperatif Dengan Pendekatan Experiental Learning Untuk Meningkatkan Keterampilan Sosial. Mimbar Sekolah Dasar, 2(2), 140-151.

Isbayani, N. S., Sulastri, N. M., \& Tirtayani, L. A. (2015). Penerapan Metode Outbound Untuk Meningkatkan Keterampilan Sosial Emosional Anak. E-Journal PG PAUD Universitas Pendidikan Ganesha, 3(1).

Izzati, N. (2014). Pengaruh Keterampilan Sosial Terhadap Kemampuan Komunikasi Matematis Mahasiswa. Jurnal Edueksos, III(1), 87-100.

Jr., P. G. C., \& Millis, B. J. (1994). Complex Cooperative Learning Structures for College and University Courses. Professional and Organizational Development Network in Higher Education, 13(1), 285-307.

Kurniati, E. (2011). Program Bimbingan Untuk Mengembangkan Keterampilan Sosial Anak Melalui Permainan Tradisional.

Maryani, E., \& Syamsudin, H. (2009). Pengembangan Program Pembelajaran Ips Untuk Meningkatkan Kompetensi Keterampilan Sosial. Jurnal Penelitian, 9(1).

Nurhikmah, Zulkarnain, \& Lusi N, I. (2017). Pengaruh Model Complex Instruction Terhadap Hasil Belajar Geografi Siswa Kelas Xi.

Nurokhman, W. (2014). Eksperimentasi Pembelajaran Matematika Model CLS dengan Teknik Berkirim Salam dan Soal SMP Negeri 3 Gombong. EKUIVALENPendidikan Matematik, 10(1).

Nursafitri, E., Ahmad, A. A., \& Shavab, O. A. K. (2020). Pengaruh Model Pembelajaran Kooperatif Tipe Complex Instruction Terhadap Hasil Belajar Siswa Pada Mata 
Pelajaran Sejarah Indonesia. Bihari: Pendidikan Sejarah Dan Ilmu Sejarah, 3(1), 284-291.

Oslund, J. A. (2016). After the elementary mathematics teacher workshop: Stories of becoming complex instruction teachers. Elementary School Journal, 116(3), 437458.

Perdani, P. A. (2013). Peningkatan Keterampilan Sosial Melalui Metode Bermain Permainan Tradisional Pada Anak TK B. Jurnal Pendidikan Usia Dini, 7(2).

Perdani, P. A. (2014). Peningkatan Keterampilan Sosial Anak Melalui Permainan Tradisional. Jurnal Pendidikan Usia Dini, 8(1).

Purmintasari, Y. D., \& Lestari, A. (2016). Pengaruh Model Pembelajaran Kooperatif Tipe Complex Instruction Terhadap Hasil Belajar IPS. SOCIA: Jurnal Ilmu-Ilmu Sosial, $15(1), 1$.

Purwaningsih, A. (2018). Penerapan Model Pembelajaran Cooperative Learning Structure Untuk Meningkatkan Keaktifan Belajar Dan Prestasi Belajar Bahasa Inggris Tentang Conditional Sentence Pada Siswa Kelas Xi-Tgb-A SMKN 2 Surakarta Semester Genap Tahun Ajaran 2017/2018. Indonesian Journal on Education and Research, 3(1).

Rukmana, F. I. H. (2017). EFEKTIFITAS METODE KOOPERATIF DALAM PEMBELAJARAN BAHASA ARAB. Prosiding Konfererensi Nasional Bahasa Arab III.

Samosir, F. S., \& Silitonga, M. (2014). Penerapan Pembelajaran Kooperatif Tipe Pengajaran Kompleks (Complex Intruction) Dalam Pembelajaran Kompetensi Menganalisis Rangkaian Kemagnetan. Jurnal Pendidikan Teknologi Dan Kejuruan, 15(1), 68-78.

Siska, Y. (2011). Penerapan Metode Bermain Peran (Role Playing) Dalam Meningkatkan Keterampilan Sosial Dan Keterampilan Berbicara Anak Usia Dini. Jurnal Educ, l(1).

Suherman, A. (2016). Pengaruh Penerapan Model Kooperatif Tipe Jigsaw Dan Tgt (Teams Game Tournament) Terhadap Keterampilan Sosial Dan Keterampilan Bermain Bolavoli. Jurnal Pendidikan Jasmani Dan Olahraga, l(2).

Vhalery, R. (2019). PERBANDINGAN AKTIVITAS BELAJAR MELALUI MODEL PEMBELAJARAN KOOPERATIF TIPE GROUP INVESTIGATION DAN NUMBERED HEAD TOGETHER. Research and Development Journal of Education, 6(1), 80-93.

Vhalery, R. (2019). Perbandingan Model Pembelajaran Kooperatif Tipe Gallery Walk Dengan Tipe Learning Together Pada Aktivitas Belajar Peserta Didik Di SMA Tri Dharma Palembang. Jurnal Inovasi Pendidikan Ekonomi (JIPE), 9(1), 01-10.

Wardani, W. (2019). Pengaruh kecerdasan adversitas dan kecerdasan emosional melalui model inkuiri sosial terhadap keterampilan sosial siswa. Jurnal Teori Dan Praksis Pembelajaran IPS, 4(2), 66-73.

Wineburg, M. S. (1995). The process of peer coaching in the implementation of cooperative learning structures. American Educational Research Association. 